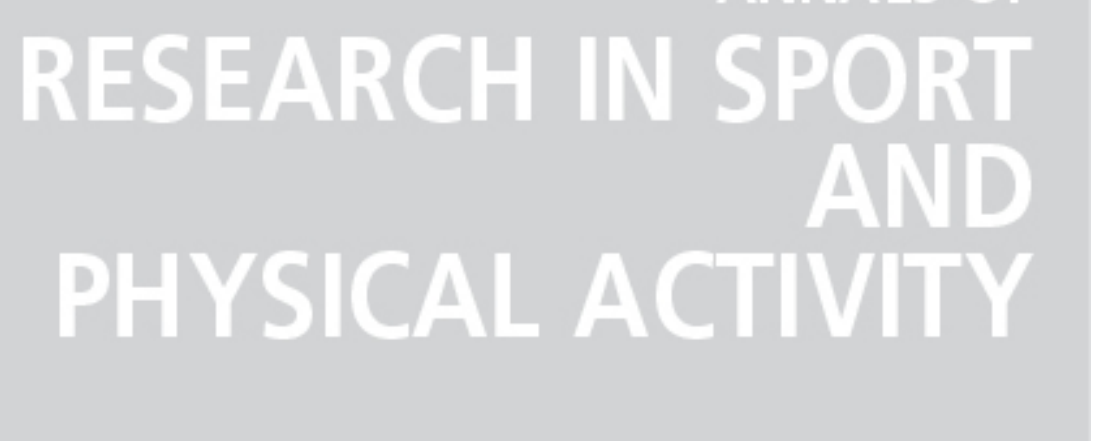

\title{
What discriminates elite and sub-elite youth field hockey players
}

$\begin{array}{ll}\text { Autor(es): } & \text { Elferink-Gemser, Marije T.; Starkes, Janet L.; Medic, Nikola; Lemmink, } \\ \text { Koen A.P.M.; Visscher, Chris }\end{array}$

Publicado por: Imprensa da Universidade de Coimbra

URL persistente:

URI:http://hdl.handle.net/10316.2/3362

DOI:

DOI:http://dx.doi.org/10.14195/2182-7087_1_3

Accessed : $\quad$ 26-Apr-2023 14:33:56

A navegação consulta e descarregamento dos títulos inseridos nas Bibliotecas Digitais UC Digitalis, UC Pombalina e UC Impactum, pressupõem a aceitação plena e sem reservas dos Termos e Condições de Uso destas Bibliotecas Digitais, disponíveis em https://digitalis.uc.pt/pt-pt/termos.

Conforme exposto nos referidos Termos e Condições de Uso, o descarregamento de títulos de acesso restrito requer uma licença válida de autorização devendo o utilizador aceder ao(s) documento(s) a partir de um endereço de IP da instituição detentora da supramencionada licença.

Ao utilizador é apenas permitido o descarregamento para uso pessoal, pelo que o emprego do(s) título(s) descarregado(s) para outro fim, designadamente comercial, carece de autorização do respetivo autor ou editor da obra.

Na medida em que todas as obras da UC Digitalis se encontram protegidas pelo Código do Direito de Autor e Direitos Conexos e demais legislação aplicável, toda a cópia, parcial ou total, deste documento, nos casos em que é legalmente admitida, deverá conter ou fazer-se acompanhar por este aviso. 
(1) 2011

\section{ANNALS OF RESEARCH IN SPORT PHYSICAL ACTIVITY

FACULDADE DE

CIÊNCIAS DO DESPORTO E EDUCAÇÃO FÍSICA DA UNIVERSIDADE DE COIMBRA IMPRENSA DA UNIVERISDADE DE COIMBRA 
3• SPORT TRAINING

WHAT DISCRIMINATES ELITE AND SUB-ELITE YOUTH FIELD HOCKEY PLAYERS? 
Marije T. Elferink-Gemser ${ }^{1}$, Janet L. Starkes², Nikola Medic ${ }^{3}$,

Koen A.P.M. Lemmink, Chris Visscher

\begin{abstract}
To investigate in young (mean age 13.4, $s=0.35$ ) and older players (mean age 17.1, $s=0.70$ ) which combination of measures best predicts if a talented field hockey player is considered youth elite or youth sub-elite, 224 talented field hockey players $(n=63$ youth elite; $n=161$ youth sub-elite) completed a multidimensional test battery with measures for training, anthropometric and physiological characteristics, technical skill, self-reported cognitive skills in tactical decisions, and psychological characteristics. Discriminant analyses with Z-scores explained $40 \%$ of variance in young and $51 \%$ in older players, with correct prediction of group membership of $70.1 \%$ and $78.7 \%$, respectively. Specific training and field hockey skill best discriminated between elite and sub-elite players. It is recommended that in talent identification, attention is paid to the combination of several multidimensional performance characteristics, whereas in talent development accumulated sport-specific training in particular seems to increase levels of performance.
\end{abstract}

KEYWORDS: talent identification, talent development, multidimensional performance characteristics, specificity of training.

\title{
INTRODUCTION
}

There is a long history in psychology of using multidimensional test batteries to predict either expert performance or the probability of attaining expert levels of performance in tasks that involve a combination of perceptual and motor skills (e.g., Damos, 1996; Fleishman,

\footnotetext{
${ }^{1}$ Center for Human Movement Sciences, University Medical Center Groningen, The Netherlands First and corresponding author: Marije T. Elferink-Gemser.

Center for Human Movement Sciences, University Medical Center Groningen, University of Groningen, A. Deusinglaan 1, 9713 AV Groningen, The Netherlands, Tel.+31 503632616 / 2719, Fax +31 503633150 , m.t.elferink-gemser@med.umcg.nl.

2 Department of Kinesiology, McMaster University, Hamilton, Canada.

${ }^{3}$ School of Exercise, Biomedical and Health Sciences, Edith Cowan University, Perth, Australia.
} 
1966; Hunter \& Burke, 1994; Starkes, 1987). An advantage of doing so is that in cases where training an individual is long or expensive, those costs and time can be controlled by selecting trainees who are most likely to be successful and thereby decrease failure or attrition rate (talent identification). Facilities and resources can thus be committed more effectively.

Not surprisingly, in sport the underlying components of expertise have been found to be not only physical in nature but also include sport specific technical and tactical aspects, as well as motivation (Helsen \& Starkes, 1999; Reilly, Williams, Nevill, \& Franks, 2000; Starkes, 1987). Two studies focused on visual/perceptual skills and sport specific cognitive skills were able to predict a significant proportion of variance in expert performance $\left(r^{2}=0.69\right.$ Starkes, $1987 ; r^{2}=0.84$ Helsen \& Starkes, 1999) via tasks that involved shot prediction, decision accuracy, tactical solutions, and recall of game information. These two studies were limited however, because they employed groups (experts/novices) that were already highly differentiated by skills. One important feature of talent development is that the best determinants of initial task performance are usually not the same as the best determinants of final task performance, that is, what distinguishes a person early in their training is not what does so as experts. Unfortunately, in the expertise literature the vast majority of studies have focused solely on expert-novice comparisons. However, from a talent development perspective it is more important to be able to differentiate among levels of expertise, or elite from sub-elite players. Reilly et al. (2000) applied a multidisciplinary approach to talent identification in soccer and successfully discriminated between groups of elite and sub-elite soccer players. However, the sub-elite players in their study were fairly low in skill. It is unclear whether their multivariate test battery would be sensitive enough to discriminate between levels of talented athletes already exposed to high-level training. Reilly et al., themselves, questioned the sensitivity with elite performers.

One confounding factor in the identification of elite versus sub-elite players is that the development of expert performance is usually concentrated in the period as the person is transitioning through adolescence. Three stages of talent development from childhood to late adolescence have been identified that are specific to sport: the sampling years (ages 6-12), the specializing years (ages 13-15), and the investment years (age 16+) (Côté, 1999; Côté, Baker, \& Abernethy, 2003). Transitions between stages are characterized by significant changes in athletes' engagement in deliberate play, deliberate practice, and other sporting activities (Côté et al., 2003). In the later stages, athletes spend less time in deliberate play and other sporting activities, and more time in deliberate practice in their primary sport (Côté \& Hay, 2002). It is unknown, however, which combination of multidimensional performance characteristics best predicts athletes' success at each stage development.

It has been found that time spent in deliberate practice is directly related to expertise in different domains including sports (Ericsson, 1996; 2002; 2003; Charness, Krampe, \& Mayr, 1996). Although the likelihood of reaching an international level in sports is not linearly related to the number of hours invested in practice, eventual experts have typically been found 
to deliberately train for at least ten years before reaching the top (e.g., Ericsson, 1996; Ericsson, Krampe, \& Tesch-Römer, 1993; Starkes, 2000; Starkes, Deakin, Allard, Hodges, \& Hayes, 1996). Talented athletes therefore train and compete for many years in order to prepare for the international sporting arena.

In the Netherlands, field hockey is a popular sport and the high level of the Dutch field hockey competition is recognized internationally. There are 172,477 competitive field hockey players ( $n=73,931$ adult players and $n=98,546$ youth players) in the country. Of the youth players, 1536 players (1.6\%) are considered "talented players" in that they compete at the highest national level for their age. All these players are part of a youth selection team of a field hockey club of national prestige. In our study, talented players were defined as youth players in the 12-19 age categories who perform better than peers during training and competition, and have the potential to reach the elite level (Elferink-Gemser, 2005; Helsen, Hodges, Van Winckel, \& Starkes, 2000; Howe, Davidson, \& Sloboda, 1998). In these age categories talented athletes move from the sampling years through the specializing years into the investment years. Based on their level of performance they are further divided in elite and sub-elite youth players. Elite youth players additionally play in a district- or national youth team of the Dutch Field Hockey Association (KNHB). In the Netherlands, there are 492 elite youth players, which comprise $0.5 \%$ of all Dutch youth field hockey players. Therefore the main purpose of this study was to investigate in young players (12-14 years, specializing years) as well as in older players (16-19 years, investment years) which combination of measures best predicts if a talented field hockey player is considered elite or sub-elite.

\section{METHODS}

\section{Participants}

Participants were 240 talented youth field hockey players. In order to satisfy all assumptions of multivariate tests, 16 participants were eliminated from the original data set because of partial missing data. Of the remaining 224 players, 113 were male and 111 female. All players were part of a talent development program of a field hockey club of national prestige, and were playing at the highest level for their age category in the Netherlands. They were provided highly qualified trainers and good training facilities. Based on age and level of performance, players were divided into younger (12-14 years; $n=97)$ and older players (16-19 years; $n=127)$, and into elite $(n=63)$ and sub-elite youth players $(n=161)$. In addition to playing in their club's selection team, Dutch players who are considered to be current elite youth players are invited to train and play in a youth selection team of the 
Dutch Field Hockey Association. Talented players who are considered to be current subelite youth players only play in their club's selection team. This distinction was also adopted in this study. Further descriptive information on participants is presented in Table 1 and as part of the results in Table 2.

\section{Measures}

Players completed a test battery at the end of their competitive field hockey season. The test battery consisted of measures in six categories: training characteristics (3 variables), anthropometric characteristics (2 variables), physiological characteristics (2 variables), technical skills (1 variable), self-reported cognitive skills in tactical decisions (4 variables), and psychological characteristics (3 variables). The employed test procedures are described briefly herein and elsewhere in greater detail should a researcher wish to replicate them (Elferink-Gemser, 2005; Elferink-Gemser, Visscher, Lemmink, \& Mulder, 2004).

\section{Training characteristics}

In a questionnaire players were asked how many years they had played competitive field hockey. Players also filled in the number of field hockey training sessions they attended per week and the duration of these training sessions. In the Netherlands, the competitive field hockey season has a duration of approximately 43 weeks, starting in September and ending in June. Thus accumulated specific field hockey practice to date was estimated by multiplying the number of field hockey practice hours per week by 43 , by the years of field hockey experience. In addition, players were asked how many field hockey matches they played per week and how many hours per week they trained in other sports, or by themselves, throughout the year. Time spent in physical education at school, which was on average 2.5 hours per week, was excluded. The variables representing training characteristics for the present study were accumulated field hockey practice (hours), non-field hockey practice (hours/week), and number of field hockey matches per week.

\section{Anthropometric characteristics}

The anthropometric measurements employed were height $(\mathrm{m})$, body weight $(\mathrm{kg})$ and percent body fat. The latter was estimated by means of leg-to-leg bioelectrical impedance analysis (BIA; Valhalla BIA, Valhalla, Inc., San Diego, CA). Bioelectrical impedance analysis is often used to estimate fat free mass and fat components (Lukaski, 1990). The method used in this study proved to be reliable for measuring percent body fat, and results cor- 
related highly with percent body fat as measured with underwater weighing and dual X-ray absorptiometry (Nunez, Callagher, Visser, Pi-Sunyer, Wang, \& Heymsfield, 1997). Lean body mass was calculated from body weight and percentage body fat. The variables representing anthropometric characteristics for the present study were height $(\mathrm{m})$ and lean body mass $(\mathrm{kg})$.

\section{Physiological characteristics}

Players performed two field tests: the Shuttle Sprint and Dribble Test (ShuttleSDT; Lemmink, Elferink-Gemser, \& Visscher, 2004) and the Interval Shuttle Run Test (ISRT; Lemmink \& Visscher, 2003) to measure both anaerobic (30m shuttle sprint) and aerobic aspects of field hockey performance (interval endurance capacity). In the ShuttleSDT, players had to run three $30-\mathrm{m}$ sprints with 180-degree turning points. Each 30-meter sprint consisted of $5 \mathrm{~m}$ to-and-fro, directly followed by $10 \mathrm{~m}$ to-and-fro. The $30 \mathrm{~m}$ shuttle sprint was derived by the time covered in the fastest of three $30-\mathrm{m}$ sprints. In a previous study, relative and absolute test-retest reliability of the ShuttleSDT were supported (ICC $=0.81$ and zero lay within the $95 \%$ confidence interval of the mean differences). In addition, this test was sensitive for differences in level of performance (Lemmink, Elferink-Gemser, et al., 2004). The ISRT for interval endurance capacity is a field test that contains intervals at a work-rest ratio of 2:1, turning points at $20 \mathrm{~m}$ and an increasing running velocity. The number of fully completed 20-m runs was recorded as the test score. In previous research, this test has been shown to be reliable and sensitive for differences in performance level (Lemmink, Verheijen, \& Visscher, 2004; Lemmink, Visscher, Lambert, \& Lamberts, 2004). In both tests, players had to carry their hockey stick and complete the movements as they would in a game. The variables representing physiological characteristics for the present study were $30 \mathrm{~m}$ shuttle sprint (s) and interval endurance capacity (number of $20 \mathrm{~m}$ runs).

\section{Technical skills}

The slalom dribble performance was measured using the Slalom Sprint and Dribble Test (SlalomSDT; Lemmink, Elferink-Gemser, et al., 2004), in which players had to dribble $30 \mathrm{~m}$ in a zigzag fashion with twelve 120-degree turns around cones placed $2 \mathrm{~m}$ apart. In a previous study, this test has been shown to be reliable and sensitive for differences in performance level (ICC $=0.78$ and zero lay within the $95 \%$ confidence interval of the mean differences) (Lemmink, Elferink-Gemser, et al., 2004). The variable representing technical skill for the present study was performance in a slalom dribble (s). 


\section{Self-reported cognitive skills in tactical decisions}

Players filled in a 23-item questionnaire to assess self-reported cognitive skills in tactical decisions (TACSIS; Elferink-Gemser, Visscher, Richart, \& Lemmink, 2004). In the TACSIS, players were asked to judge themselves on a 6 -point Likert scale ranging from very poor to excellent or from almost never to always, while comparing oneself with top players in the same age category. The TACSIS contains four subscales, with two subscales more related to declarative knowledge ('Predicting ball actions' and 'Anticipation of actions of others') and two more related to procedural knowledge ('Positioning and deciding' and 'Choice of appropriate action in dynamic situations'). In previous research on youth athletes in the age categories 12 - 18 years, both relative and absolute test-retest reliability was supported (ICC varying from 0.76 to 0.89 and zero lay within the $95 \%$ confidence interval of the mean differences). Internal consistency estimates for the scales ranged from 0.72 to 0.89 . The TACSIS has also been shown to be sensitive for differences in performance level (Elferink-Gemser, Visscher, Richart, et al., 2004). The variables representing self reported cognitive skills in tactical decisions for the present study were positioning and deciding, predicting ball actions, anticipation of actions of others, and choice of appropriate action in dynamic situations.

\section{Psychological characteristics}

Two types of dispositional goal orientations (i.e., task and ego goal orientation) were assessed using the Task and Ego Orientation in Sport Questionnaire (TEOSQ; Duda \& Nicholls, 1992). In the TEOSQ, players were asked to indicate on a 5-point Likert scale, where 1 represented "strongly disagree" and 5 represented "strongly agree", to what extent they agreed with each of the 13 items. Each item consisted of a statement following the stem, "I feel successful in field hockey when....". Duda (1992) reported internal consistency coefficients of the TEOSQ ranging from Cronbach's alpha 0.81 to 0.86 for task orientation and from 0.79 to 0.90 for ego orientation. Because of the nationality of the participants, the players filled out the Dutch translation of the TEOSQ (Van Yperen \& Duda, 1994). Internal consistency coefficients of the Dutch translation of the TEOSQ ranged from 0.84 to 0.88 for task orientation and were repeatedly 0.82 for ego orientation. Players also filled in the motivation scale of the Dutch Youth Version of the Psychological Skills Inventory for Sports (PSIS-Youth; ElferinkGemser, 2005) which was based on the Psychological Skills Inventory for Sports (PSIS-R-5; Mahoney, Gabriel, \& Perkins, 1987). Scores were measured using a 5-point Likert scale (1 = almost never, 5 = almost always). Internal consistency for the motivation scale was 0.77 , which was very similar to other studies that used the PSIS-R-5 (e.g., Mahoney, 1989; White, 1993; White \& Croce, 1992). The variables representing psychological characteristics for the present study were task orientation, ego orientation, and motivation. 


\section{Procedures}

All players/parents were informed about the procedures employed in the study and they provided informed consent to participate. The field hockey clubs and trainers gave their permission for this study as all procedures were in accordance with the standards of the ethics committee of the University of Groningen. The players completed the tests at the end of the competitive field hockey season. Ambient temperature, humidity and wind conditions were documented. Field tests were executed on synthetic field hockey playing surfaces. A waterbased pitch was used, which is the most modern, fast, and technically difficult to play on. After having completed the field tests, players filled in questionnaires individually in a group setting. Players were told that the results would be used anonymously and were asked to fill in the questionnaires honestly to ensure maximum accuracy and validity of the results.

\section{Data analyses}

Mean scores and standard deviations were calculated for each variable for the different subgroups according to the six categories of the test battery. In addition, the effect sizes ( $d$ ) between elite and sub-elite players were calculated. Cohen (1988) suggested that effect sizes around 0.20 are small, around 0.50 are moderate and around 0.80 are large.

Two preliminary analyses (MANOVA), one for young and one for older players with the factors of performance level and gender and the 15 multidimensional performance characteristics as dependent variables, revealed significant main effects for performance level (for young players $F_{15,79}=2.25, P<0.05$; for older players $F_{15,109}=3.21, P<0.01$ ) and gender (for young players $F_{15,79}=2.46, P<0.01$; for older players $\left.F_{15,109}=3.21, P<0.01\right)$ but no significant interaction effects between performance level and gender (for young players $F_{15,79}=0.97$, $P=0.495$; for older players $F_{15,109}=1.00, P=0.459$ ). The absence of an interaction effect in combination with the ratio of male to female players being similar for elite and sub-elite players in young as well as in older players (see Table 1) supported our decision to collapse across gender to increase sample size.

Table 1. Number of Male and Female, Young and Older, Elite and Sub-Elite Talented Field Hockey Players

\begin{tabular}{|c|c|c|c|c|}
\multicolumn{2}{c|}{} & \multicolumn{2}{c}{$\begin{array}{c}\text { Young players } \\
\text { (12-14 years) }\end{array}$} & \multicolumn{2}{c|}{$\begin{array}{c}\text { Older players } \\
\text { (16-19 years) }\end{array}$} \\
\cline { 2 - 5 } & Male & Female & Male & Female \\
\hline Elite & 17 & 14 & 14 & 18 \\
\hline Sub-elite & 32 & 34 & 50 & 45 \\
\hline
\end{tabular}


Raw scores of the 15 multidimensional performance characteristics were transformed to standardized Z-scores for young and older players separately in order to make cross task comparisons possible. In the young and older players, Z-scores of all variables were analyzed together to determine which combination of measures best discriminated between elite and sub-elite players. A stepwise discriminant function analysis was used in which level of performance was the dependent variable.

\section{RESULTS}

Table 2 presents means and standard deviations of the multidimensional performance characteristics of young and older talented field hockey players together with effect sizes between elite and sub-elite players.

In both age groups, effect sizes for training characteristics and technical skill were small to moderate, for anthropometric and physiological characteristics as well as for self-reported cognitive and psychological characteristics effect sizes were small, indicating the homogeneity of the sample. Figure 1 shows the Z-scores on the 15 multidimensional performance characteristics of the elite and sub-elite players in young as well as in older talented field hockey players, as well as all the effect sizes $>0.20$.

\section{Figure Caption}

Figure 1. Z-scores on multidimensional performance characteristics in young and older talented field hockey players.

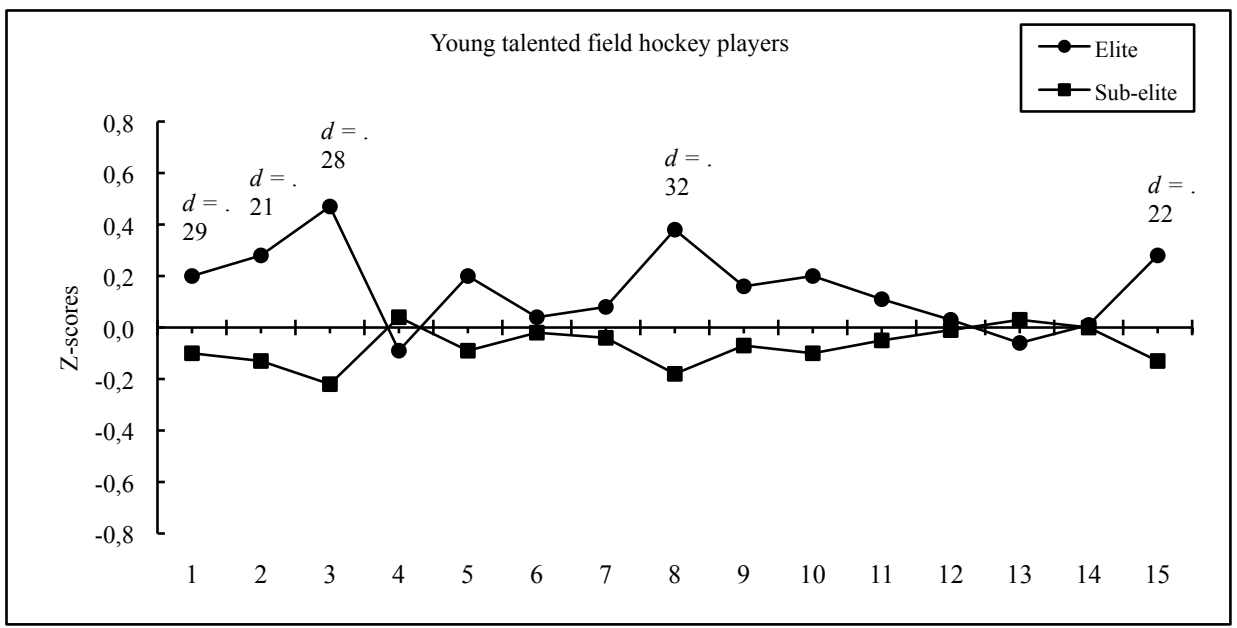




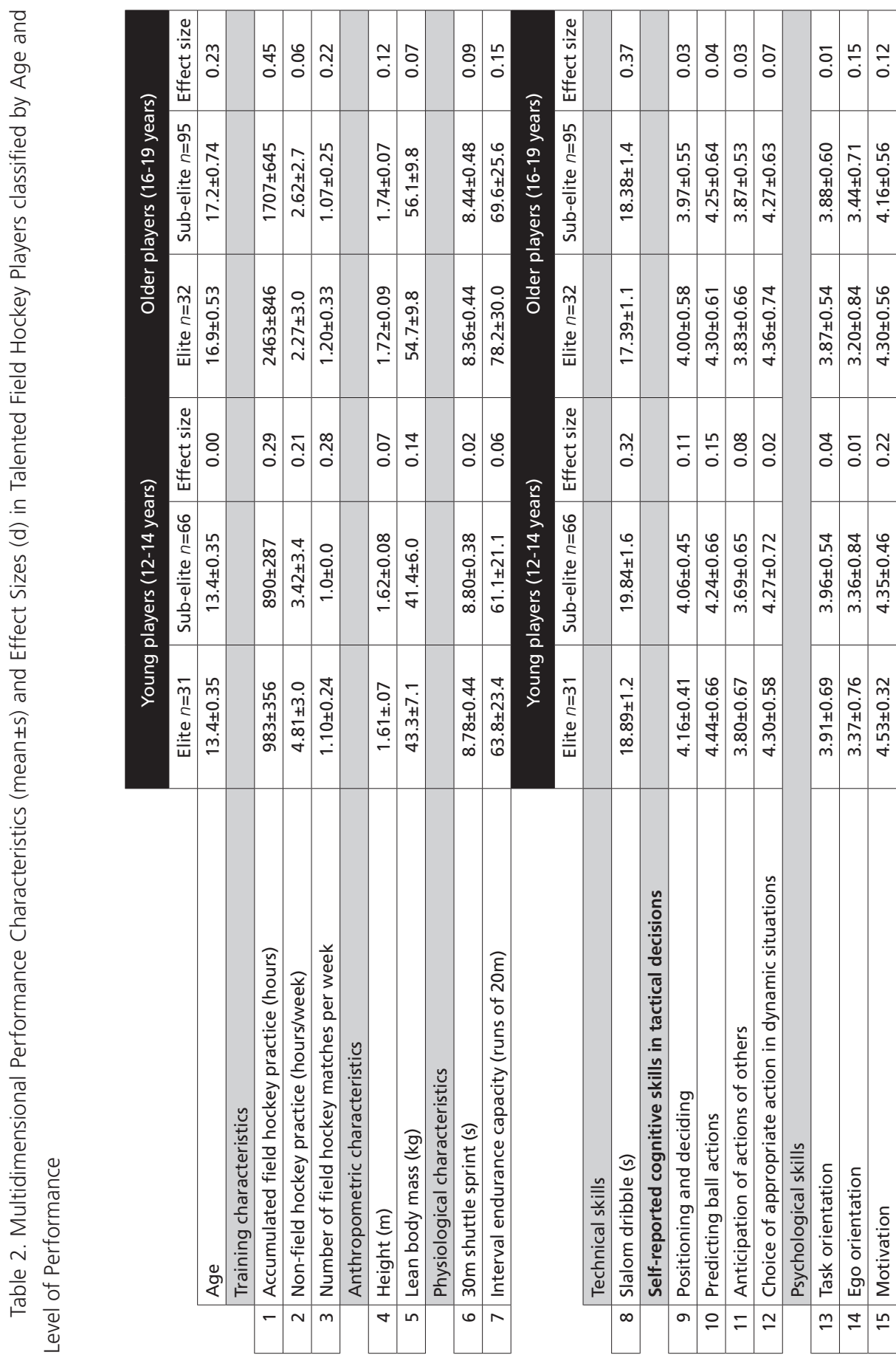




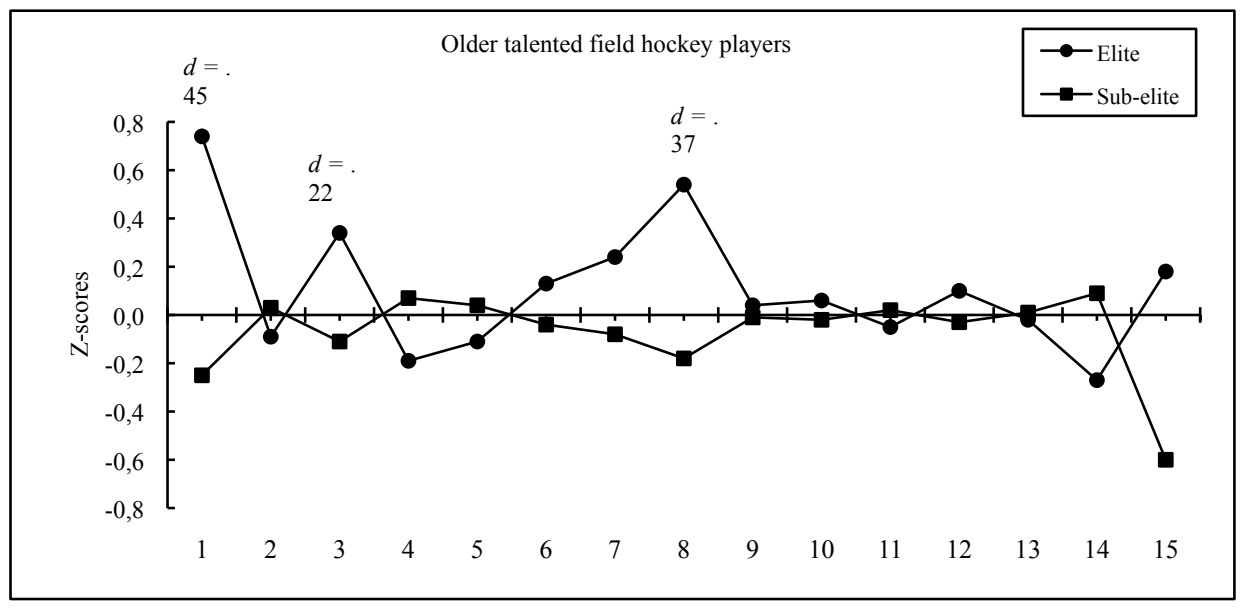

Note. The 15 multidimensional performance characteristics on the $\mathrm{X}$-axes are: 1 . Accumulated field hockey practice, 2. Non-field hockey practice, 3. Number of field hockey matches per week, 4. Height, 5. Lean body mass, 6. 30m Shuttle sprint, 7. Interval endurance capacity, 8. Slalom dribble, 9. Positioning and deciding, 10. Predicting ball actions, 11. Anticipation of actions of others, 12. Choice of appropriate action in dynamic situations, 13. Task orientation, 14. Ego orientation, 15. Motivation.

The results of the stepwise discriminant analysis are presented in Tables 3 and 4 . The model for the younger players predicted that a combination of two variables successfully discriminated between the elite and sub-elite players. These measures were: number of field hockey matches per week (0.78) and performance in a slalom dribble (0.61). The average squared canonical correlation was 0.40 . This means that, by knowing the number of field hockey matches per week and the performance in a slalom dribble, the estimation of the percent of variance accounted for is $40 \%$. When group membership is predicted from these two variables, $70.1 \%$ of the original grouped players are classified correctly. The other variables provided no additional information when discriminating further between the two groups of players. 
Table 3. Summary of Stepwise Discriminant Analysis for Young Talented Field Hockey Players

Step Entered
\begin{tabular}{|c|c|c|c|c|c|c|c|c|c|c|}
\hline & Wilks' Lambda \\
\cline { 2 - 13 } & Statistic & df1 & df2 & df3 & \multicolumn{5}{c|}{ Exact $F$} \\
\hline 1 & Matches per week & 0.90 & 1 & 1 & 95 & 10.98 & 1 & 95 & 0.001 \\
\hline 2 & Slalom dribble & 0.84 & 2 & 1 & 95 & 8.7 & 2 & 94 & $<0.001$ \\
\hline
\end{tabular}

Note. At each step, the variable that minimizes the overall Wilks' Lambda is entered.

Maximum number of steps is 30 . Minimum partial $F$ to enter is 3.84 . Maximum partial $F$ to remove is 2.71 .

\begin{tabular}{|c|c|c|c|c|}
\hline Step & & Tolerance & $F$ to Remove & Wilks' Lambda \\
\hline 1 & Matches per week & 1.00 & 10.98 & \\
\hline \multirow[t]{2}{*}{2} & Matches per week & 1.00 & 9.90 & 0.93 \\
\hline & Slalom dribble & 1.00 & 5.84 & 0.90 \\
\hline
\end{tabular}

The model for the older players predicted that a combination of three variables would successfully discriminate between the elite and sub-elite players. These measures were: accumulated field hockey practice (0.75), performance in a slalom dribble (0.59), and height (0.36). The average squared canonical correlation was 0.51 with the percent of variance accounted for $51 \%$. When group membership is predicted from these three variables, $78.7 \%$ of the original grouped players are classified correctly. The other variables provided no additional information when discriminating further between the two groups of players.

Table 4. Summary of Stepwise Discriminant analysis for Older Talented Field Hockey Players

\begin{tabular}{|c|c|c|c|c|c|c|c|c|c|}
\hline \multirow{3}{*}{ Step } & \multirow[t]{3}{*}{ Entered } & \multicolumn{8}{|c|}{ Wilks' Lambda } \\
\hline & & Statistic & df1 & $d f 2$ & df3 & \multicolumn{4}{|c|}{ Exact $F$} \\
\hline & & & & & & Statistic & df1 & $\mathrm{df2}$ & $P$ \\
\hline 1 & Acc. field hockey practice & 0.82 & 1 & 1 & 125 & 28.29 & 1 & 125 & $<0.001$ \\
\hline 2 & Slalom dribble & 0.77 & 2 & 1 & 125 & 19.05 & 2 & 124 & $<0.001$ \\
\hline 3 & Height & 0.74 & 3 & 1 & 125 & 14.28 & 3 & 123 & $<0.001$ \\
\hline
\end{tabular}

Note. At each step, the variable that minimizes the overall Wilks' Lambda is entered.

Maximum number of steps is 30 . Minimum partial $F$ to enter is 3.84 . Maximum partial $F$ to remove is 2.71 . 


\begin{tabular}{|r|l|c|c|c|}
\multicolumn{1}{|l}{ Step } & & Tolerance & \multicolumn{1}{c|}{ F to Remove } & Wilks' Lambda \\
\hline 1 & Acc. field hockey practice & 1.00 & 28.29 & \\
\hline 2 & Acc. field hockey practice & 0.99 & 22.14 & 0.90 \\
\hline & Slalom dribble & 0.99 & 8.19 & 0.82 \\
\hline 3 & Acc. field hockey practice & 0.99 & 20.52 & 0.87 \\
\hline \multirow{2}{*}{} & Slalom dribble & 0.91 & 10.80 & 0.81 \\
\cline { 2 - 5 } & Height & 0.91 & 3.85 & 0.77 \\
\cline { 2 - 5 }
\end{tabular}

\section{DISCUSSION}

The goal of this study was to investigate in young players (12-14 years) as well as in older players (16-19 years) which combination of measures best predicted if a talented field hockey player was considered elite or sub-elite. Results showed that in both young and older players specific training characteristics (i.e., field hockey specific training and field hockey matches) are important predictors of level of performance. When skill levels increase from the specializing to the investment years, specificity of training becomes increasingly important in contrast to non-specific practice. A potential limitation of this study, however, is that it remains unclear how far this specific training is a consequence rather than a cause of the split between the two performance levels.

According to Baker, Côté, and Abernethy (2003) time spent in organized training and competition are helpful to developing those abilities necessary for success in team ball sports including field hockey, such as perception, decision making, movement execution, and physical fitness. In our study, organized training and competition consisted of specific field hockey practice and field hockey matches both of which we consider elements of deliberate practice. In their theory of deliberate practice (based on studying expert performance in musicians), Ericsson et al. (1993) argued that only practice activities structured to improve current performance, that were highly relevant to the particular domain, that required concerted effort to complete, and that were not inherently enjoyable were considered to be deliberate practice. Specific field hockey practice and field hockey meet only the first three aspects of the definition. This seems contrary to the definition of deliberate practice, but in line with other studies on sports which have found those forms of practice closest to game conditions are rated as most relevant to performance, but also most enjoyable (e.g., figure skating: Starkes et al., 1996; Deakin \& Cobley, 2003; wrestling: Hodges \& Starkes, 1996; Starkes et al., 1996; soccer and field hockey: Helsen, Starkes, \& Hodges, 1998; martial arts: Hodge \& Deakin, 1998). Elsewhere, Hodges and colleagues (Hodges, Kerr, Starkes, Weir, \& Nananidou, 2004) have suggested that the enjoyment construct may have been somewhat confounded in earlier studies of music and sport by the nature of the questions re enjoyment, and provide recommendations re the timing of questionnaires relative to the actual practice performed. 
In line with previous studies (e.g., Elferink-Gemser et al., 2004; Franks, Williams, Reilly, \& Nevill, 1999), results showed that in young as well as in older players, not anthropometric or physiological characteristics but rather the most specific measure of field hockey performance (i.e., slalom dribble) explained a great portion of variance accounted for when discriminating between elite and sub-elite players. A practical consequence is that it appears that every test battery attempting to measure level of performance in talented athletes should contain sport-specific measures.

Although maturity status is closely related to size and body composition, variables we did include in the study, a limitation of this study is that no measures of biological maturity status were obtained (e.g., Malina, Pena Reyes, Eisenmann, Horta, Rodrigues, \& Miller, 2000). However, it cannot be ruled out that there is an interaction effect of physical and physiological characteristics and individual differences in the timing and tempo of biological maturation (Malina, 2004). Maturity is shown to be a predictor of functional capacity and skill in youth soccer players (Figueiredo, Coelho e Silva, \& Malina, 2010) and differences in maturity status may be related to level of performance (e.g., Coelho e Silva et al., 2010a; 2010b). Also, in the 12-14 year age-band considerable differences may exist between boys and girls in maturity status. Therefore, a gender-specific analysis would probably be more precise, however, our sample size was too small to perform such analyses. Nevertheless, we were primarily interested in which combination of measures best predicts if a talented field hockey player is considered elite or sub-elite in players in their specializing years versus players in their investment years. Since our preliminary analysis showed no interaction effect between gender and performance level, the ratio between the multidimensional performance characteristics in young and older players is considered similar for boys and girls. This means that the results can be applied to either boys and girls.

In the present study, over $70 \%$ of the players were correctly classified by the discriminant function analyses. The corollary is that over $20 \%$ were incorrectly classified, showing that the test battery is still relative insensitive. However, so far most research on expertise has compared expert performers with non-experts (e.g., Baker et al., 2003; Helsen \& Starkes, 1999; Starkes, 1987) whereas in this study, we attempted to discriminate elite versus sub-elite players from a highly skilled population of talented field hockey players. Participants were playing at the highest national competition for their age and were within the top $1.6 \%$ of all youth field hockey players in the Netherlands. The homogeneity of these players in terms of their level of performance makes it extremely difficult to measure differences in performance characteristics. Thus, those measures which can discriminate between levels of performance are particularly important.

The relative homogeneity of skill amongst the participants may be a possible explanation for the results we found regarding self-reported cognitive skills in tactical decisions and psychological characteristics. Although we found no significant differences between elite and 
sub-elite players, the directions of the differences were as expected, with elite players having higher scores than sub-elite players. In addition, all players scored high on motivation; with scores of both elite and sub-elite players exceeding 4 on a 5-point Likert scale. The importance of a high level of motivation in talented athletes is logical considering that effort and persistence are inherent requisites of deliberate practice (e.g., Ericsson et al., 1993; Helsen et al., 1998).

The results of this study have practical value for both talent identification and talent development. Talent identification refers to the process of recognizing youth players with the potential to become elite players whereas talent development implies that these players are provided with a suitable learning environment and resources so that they have the opportunity to realize their potential (Régnier, Salmela, \& Russell, 1993; Williams \& Reilly, 2000). In terms of talent identification, results showed that this group of talented athletes is highly homogeneous in performance, suggesting that in the process of recognizing talented players, attention has to be paid to the combination of several multidimensional performance characteristics. In terms of talent development, results showed that accumulated sport-specific training in particular seems important to increase levels of performance. Nevertheless, what athletes gain from training, i.e., their self-regulatory skills, might even be more important and worthwile exploring (e.g., Jonker, Elferink-Gemser, \& Visscher, 2010; Toering, ElferinkGemser, Jordet, \& Visscher, 2009).

This study was an attempt to predict relative performance within a group of highly talented athletes. These players are being followed in order to track their development longitudinally in future studies. This study shows that measures of specific training and field hockey skill seem to best discriminate between elite and sub-elite players. The homogeneity of the participant groups constitutes a challenge for all researchers interested in studying talent development and expertise to develop more fine-grained measures in order to separate those who do not make it to the top and those who ultimately succeed.

\section{ACKNOWLEDGEMENTS}

The authors gratefully acknowledge the financial support of the NOC*NSF and the assistance of all coaches and field hockey players who participated in the study. Thanks to Arjan Elferink for his help in data collection and preparation of the manuscript. 


\section{REFERENCES}

Baker, J., Côté, J., \& Abernethy, B. (2003). Learning from the experts: practice activities of expert decision makers in sport. Research Quarterly for Exercise and Sport, 74, 342-347.

Charness, N., Krampe, R. T., \& Mayr, U. (1996). The role of practice and coaching in intrepreneurial skill domains: An international comparison of life-span chess skill acquisition. In K. A. Ericsson (Ed.), The road to excellence: The acquisition of expert performance in the arts and sciences, sports, and games (pp. 51-80). Mahwah, NJ: Erlbaum.

Coelho e Silva, M.J., Figueiredo, A.J., Simões, F, Seabra, A, Natal, A, Vaeyens, R, Philippaerts, R, Cumming, S.P., Malina, R,M. (2010a). Discrimination of U-14 players by level and position. International Journal of Sports Medicine, Epub ahead of print.

Coelho e Silva MJ, Moreira Carvalho H, Gonçalves CE, Figueiredo AJ, Elferink-Gemser MT, Philippaerts RM, Malina RM (2010b). Growth, maturation, functional capacities and sport-specific skills in 12-13 yearold- basketball players. Journal of Sports Medicine and Physical Fitness,50, 174-181.

Cohen, J. (1988). Statistical power analysis for the behavioural sciences. Hillsdale, NJ: Lawrence Erlbaum Associates.

Côté, J. (1999). The influence of the family in the development of talent in sport. The Sport Psychologist, 13, 395-417.

Côté, J., \& Hay, J. (2002). Children's involvement in sport: A developmental perspective. In J. M. Silva \& D. Stevens (Eds.), Psychological foundations of sport (pp. 4884-502). Boston: Merrill.

Côté, J., Baker, J., \& Abernethy, B. (2003). From play to practice: A developmental framework for the acquisition of expertise in team sports. In J. L. Starkes \& K. A. Ericsson (Eds.), Expert performance in sports: Advances in research on sport expertise (pp. 89-113). Champaign, IL: Human Kinetics.

Damos, D. L. (1996). Pilot selection batteries: shortcomings and perspectives. International Journal of Aviation Psychology, 6, 199-209.

Deakin, J. M., \& Cobley, S. (2003). A Search for deliberate practice: An examination of the practice environments in figure skating and volleyball. In J. L. Starkes \& K. A. Ericsson (Eds.), Expert performance in sports: Advances in research on sport expertise (pp. 115-135). Champaign, IL: Human Kinetics.

Duda, J. L. (1992). Motivation in sport settings: A goal perspective approach. In G. C. Roberts (Ed.), Motivation in sport and exercise (pp. 57-91). Champaign, IL: Human Kinetics.

Duda, J. L., \& Nicholls, J. G. (1992). Dimensions of achievement motivation in schoolwork and sport. Journal of Educational Psychology, 84, 1-10.

Duda, J. L., \& Whitehead, J. (1998). Measurement of goal perspectives in the physical domain. In J. L. Duda (Ed.), Advances in sport and exercise psychology measurement (pp. 21-48). Morgantown, WV: Fitness Information Technology.

Dweck, C. S., \& Leggett, E. L. (1988). A social cognitive approach to motivation and personality. Psychological review, 95, 1-18.

Elferink-Gemser, M.T. (2005). Today's talented youth field hockey players, the stars of tomorrow? A study on talent development in field hockey. Wageningen: Ponsen \& Looijen bv. 
Elferink-Gemser, M. T., Visscher, C., Lemmink, K. A. P. M., \& Mulder, Th. (2004). Relation between multidimensional performance characteristics and level of performance in talented youth field hockey players. Journal of Sports Sciences, 22, 1053-1063.

Elferink-Gemser, M. T., Visscher, C., Richart, H., \& Lemmink, K. A. P. M. (2004). Development of the Tactical Skills Inventory for Sports. Perceptual and Motor Skills, 99, 883-895.

Ericsson, K. A. (1996). The acquisition of expert performance: An introduction to some of the issues. In K.

A. Ericsson (Ed.), The road to excellence: The acquisition of expert performance in the arts and sciences, sports and games (pp. 1-50). Mahwah, NJ: Lawrence Erlbaum Associates.

Ericsson, K. A. (2002). Attaining excellence through deliberate practice: Insights from the study of expert performance. In M. Ferrari (Ed.), The pursuit of excellence in education (pp. 21-55). Hillsdale, NJ: Erlbaum.

Ericsson, K. A. (2003). Development of elite performance and deliberate practice. In J. L. Starkes \& K. A. Ericsson (Eds.), Expert performance in sports: Advances in research on sport expertise (pp. 49-87). Champaign, IL: Human Kinetics.

Ericsson, K. A., Krampe, R. T., \& Tesch-Römer, C. (1993). The role of deliberate practice in the acquisition of expert performance. Psychological Review, 100, 363-406.

Figueiredo, A.J., Coelho e Silva, M.J., Malina, R.M. (2010). Predictors of functional capacity and skill in youth soccer players.Scandinavian Journal of Medicine and Science in Sports, Epub ahead of print.

Fleishman, B. A. (1966). Human abilities and the acquisition of skill. In B. A. Bilodeau (Ed.), Acquisition of skill (pp. 147-167). New York: Academic Press.

Franks, A., Williams, A. M., Reilly, T., \& Nevill, A. (1999). Talent identification inelite youth soccer players: Physical and physiological characteristics. Journal of Sports Sciences, 17, 812.

Helsen, W. F., \& Starkes, J. L. (1999). A multidimensional approach to skille perception and performance in sport. Applied Cognitive Psychology, 13, 1-27.

Helsen, W. F., Starkes, J. L., \& Hodges, N. J. (1998). Team sports and the theory ofdeliberate practice. Journal of Sport and Exercise Psychology, 20, 12-34.

Helsen, W. F., Hodges, N. J., Van Winckel, J., \& Starkes, J. L. (2000). The roles of talent, physical precocity and practice in the development of soccer expertise. Journal of Sports Sciences, 18, 727-736.

Hodge, T., \& Deakin, J. (1998). Deliberate practice and expertise in the martial arts: The role of context in motor recall. Journal of Sport and Exercise Psychology, 20, 260-279.

Hodges, N. J., \& Starkes, J. L. (1996). Wrestling with the nature of expertise: A sport-specific test of Ericsson, Krampe and Tesch-Römer's (1993) theory of "deliberate practice". International Journal of Sport Psychology, 27, 400-424.

Hodges, N. J., Kerr, T., Starkes, J. L., Weir, P. L., \& Nananidou, A. (2004). Predicting performance times from deliberate practice hours for triathletes and swimmers: What, when, and where is practice important? Journal of Experimental Psychology: Applied, 10, 219-237.

Howe, M. J. A., Davidson, J. W., \& Sloboda, J. A. (1998). Innate talents: Reality or myth. Behavioral and Brain Sciences, 21, 399-442. 
Hunter, D. R., \& Burke, E. F. (1994). Predicting aircraft pilot-training success: A meta-analysis of published research. International Journal of Aviation Psychology, 4, 297-313.

Jonker, L., Elferink-Gemser, M.T., Visscher, C. (2010). Differences in self-regulatory skills among talented athletes: the significance of competitive level and type of sport. Journal of Sports Sciences, 28, 901-908.

Lemmink, K. A. P. M., \& Visscher, C. (2003). The relationship between the Interval Shuttle Run Test and maximal oxygen uptake in soccer players. Journal of Human Movement Studies, 45, 219-232.

Lemmink, K. A. P. M., Elferink-Gemser, M. T., \& Visscher, C. (2004). Evaluation of the reliability of two field hockey-specific sprint and dribble tests in young field hockey players. British Journal of Sports Medicine, 38, 138-142.

Lemmink, K. A. P. M., Verheijen, R., \& Visscher, C. (2004). The discriminative power of the Interval Shuttle Run Test and the Maximal Multistage Shuttle Run Test for playing level of soccer. Journal of Sports Medicine and Physical Fitness, 44, 233-239.

Lemmink, K. A. P. M., Visscher, C., Lambert, M. I., \& Lamberts, R. (2004). The Interval Shuttle Run Test for intermittent sport players: evaluation of reliability. Journal of Strength and Conditioning Research, 18, 821-827.

Lukaski, H. C. (1990). Applications of bioelectrical impedance analysis: a critical review. Basic Life Science, 55, 365-374.

Mahoney, M.J. (1989). Psychological predictors of elite and non-elite performance in Olympic weightlifting. International Journal of Sport Psychology, 20, 1-12.

Mahoney, M. J., Gabriel, T. J., \& Perkins, T. S. (1987). Psychological skills and exceptional athletic performance. The Sport Psychologist, 1, 181-199.

Malina, R. M. (2004). Growth and maturation: Basic principles and effects of training. In M. Coelho e Silva \& R. M. Malina (Eds.), Children and youth in organized sports (pp. 137-161). Coimbra University Press.

Malina, R. M., Pena Reyes, M. E., Eisenmann, J. C., Horta, L., Rodrigues, J., \& Miller, R. (2000). Height, mass and skeletal maturity of elite Portugese soccer players aged 11-16 years. Journal of Sports Sciences, 18, 685-693.

Nunez, C., Callagher, D., Visser, M., Pi-Sunyer, F. X., Wang, Z., \& Heymsfield, S. B. (1997). Bioimpedance analysis: evaluation of leg-to-leg system based on pressure contact footpad electrodes. Medicine and Science in Sports and Exercise, 29, 524-531.

Régnier, G., Salmela, J. H., \& Russell, S. J. (1993). Talent detection and development in sport. In R. Singer, M. Murphey, \& L. K. Tennant (Eds.), A handbook of research on sports psychology (pp. 290-313). New York: Macmillan.

Reilly, T., Williams, A. M., Nevill, A. \& Franks, A. (2000). A multidisciplinary approach to talent identification in soccer. Journal of Sports Sciences, 18, 695-702.

Starkes, J. L. (1987). Skill in field hockey: The nature of the cognitive advantage. Journal of Sport Psychology, 9, 146-160.

Starkes, J. L. (2000). The road to expertise: Is practice the only determinant? International Journal of Sport Psychology, 31, 431-451. 
Starkes, J. L., Deakin, J. M., Allard, F., Hodges, N. J., \& Hayes, A. (1996). Deliberate practice in sports: What is it anyway? In K. A. Ericsson (Ed.), The road to excellence: The acquisition of expert performance in the arts and sciences, sports, and games (pp. 81-106). Mahwah, NJ: Lawrence Erlbaum.

Toering, T.T., Elferink-Gemser, M.T., Jordet, G., Visscher, C. (2009). Self Regulation and performance level of elite and non-elite youth soccer players. Journal of Sports Sciences, 27, 1509-1517.

Van Yperen, N. W., \& Duda, J. L. (1999). Goal orientations, beliefs about success, and performance improvement among young elite Dutch soccer players. Scandinavian Journal of Medicine and Science in Sports, 9, 358-364.

White, S. A. (1993). The relationship between psychological skills, experience, and practice commitment among collegiate male and female skiers. The Sport Psychologist, 7, 49-57.

White, S. A., \& Croce, R. V. (1992). Nordic disabled skiers and able-bodied skiers: An exploratory analysis of the psychological skills inventory for sports (PSIS-R5). Clinical Kinesiology, 45, 7-9.

Williams, A. M., \& Reilly, T. (2000). Talent identification and development in soccer. Journal of Sports Sciences, 18, 657-667. 